\title{
Food Value of Soft Dates Cultivated in Tunisian Coastal
}

\section{Oases}

\author{
Mohamed Ben Salah \\ Laboratory of Aridology and Oases Crops, Arid Land Institute, Nahal 6051, Tunisia
}

Received: February 16, 2015 / Accepted: May 11, 2015 / Published: May 30, 2015.

\begin{abstract}
Coastal date palm cultivars are interesting through their soft dates, their abundant and earliest production than continental cultivars. Maintaining bio-diversity in Tunisian oases has become a subject of first interest in date palm cultivation in Tunisia. Coastal oases still retain a very rich and varied plant biodiversity in comparison with the continental oases, weakened by the mono cultivation of "Deglet Nour" cultivar. Study of soft date's composition can make there well known to date consumers, help to valorize there and to help of sustainability of coastal oases ecosystem. Fresh dates from 15 cultivars was collected, dried by $80{ }^{\circ} \mathrm{C}$ in 20-24 h. Acidity was determinate by $\mathrm{pH}$ meter. Sugars were appreciated by enzymatic method. Ash and minerals was calculated by photometer and spectrometer. Chemical date composition study showed that coastal date palm cultivars are predominantly rich of carbohydrates, have a low quantity of sucrose which gives them an important dietary value. Their pH varies from 5 to 6 , classifies them as the best date quality for fresh consumption. Their richness in Total Nitrogen Matters and total minerals makes them at almost the same level as the other date palm cultivars analyzed by different authors in different areas of date palm production. Mineral composition showed that these dates are $\mathrm{K}$ and $\mathrm{P}$-rich and relatively poor in $\mathrm{Na}$ and $\mathrm{Ca}$.
\end{abstract}

Key words: Dates, coastal oases, Tunisia, chemical composition, sugars, Total Nitrogen, minerals.

\section{Introduction}

The Tunisian oases cover a total area of 36,000 ha [1]. They are distributed into three geo-topographic: Saharan oases, mountain oases and coastal oases. The first group (i) the saharan continental oasis located in the region of Nefzaoua and Jerid covers a total area of 23,500 ha (i.e. $65 \%$ of the Tunisian oases area) and characterized by the dominance of the "Deglet Nour" cultivar; (ii) the mountain oases located in Gafsa (Tameghza, Chebika and El Guettar), covering an area of 4,500 ha $(13 \%)$, include diverse cultivars with low presence of "Deglet Nour" [1, 2-8]); (iii) the coastal oases are situated on the coastal region of Gabes, cover an area of 7,000 ha (19\% of the total oases).

The tradition of the date palm production is very old in the coastal oases together with various fruit trees [9].

Corresponding author: Mohamed Ben Salah, research fields: biodiversity, oases and date palm. E-mail: bensalah_mohamed@yahoo.com.
The one cultivar production orientation in the Tunisian Saharan oases perturbed the oases ecosystem [2-7]). The coastal oases have been keeping their rich cultivar for a long time. There are forty five (45) cultivars in these oases [9]. Five cultivars constitute half of the date palm population. The "Kenta" cultivar occupies the first place with $28 \%$ of the total. "Bouhattam" and "Rochdi" occupy the second place with 9\% each. "Eguiwa" and "Lemsi" come third with $3 \%$ each enrolment [1]. Other cultivars represent $50 \%$ of the population.

The present paper presents the coastal soft date's composition. Water content, sugars (total and reducing) and proteins were studied in fresh dates. In dry dates ash and minerals was determinate.

\section{Materials and Methods}

The studied cultivars were the following: "Kenta", "Bouhattam", "Rochdi", "Eguiwa", "Lemsi”, "Smiti”, "Ksebba”, "Garn Ghazel”, “Ammari”, "Halwai 
Abiadh", "Mermella", "Mattata", "Eguiwa", "Korkobbi" and "Ftimi". These cultivars had been the subject of morphological description [10]. Majority of them are soft, have yellow color in "Khalal" stage and consumed in "Khala" or "Rutab" stage. Some are semi dry dates, have yellow red to yellow dark color and consumed in "Tamar" stage (Table 1).

The moisture dates was determined by drying the date flesh under $80^{\circ} \mathrm{C}$ temperature for $24 \mathrm{~h}$ [6]. Dates acidity was valued in juice dates with a $\mathrm{pH}$ meter calibrated at $25^{\circ} \mathrm{C}$ to $\mathrm{pH} 4$ and 7 .

The sugar content of the dates on glucose, fructose and sucrose was performed by the enzymatic method using "Boehringer Mannheim" kits. This enzymatic method was based on the principle of phosphorylation of simple sugars such as process by the French standard for determining the sugars in fruit [4].
Calcium, sodium and potassium rates were determined by the flame photometer. Phosphorus content was determined by the ultra violet spectrometer at $430 \mathrm{~nm}$.

\section{Results and Discussions}

\subsection{Moisture Content of Dates}

The water content in dates (Fig. 1) varies from 56\% of the fresh pulp weight of the "Halwai Abiadh" date to $51 \%$ for "Korkobbi" to a minimum of $20 \%$ of "Smiti" cultivar. Satsitical analysis (Table 3) shows significant difference between cultivars. To conserve dates, it'sconsidered that this rate should not exceed $20 \%[3,6,11,12]$. This is the case for cultivars such as "Smiti". Other cultivars storage can be better made under improved conditions (low temperature).

Table 1 Date palm trees in different regions of Tunisia.

\begin{tabular}{lllll}
\hline \multirow{2}{*}{ Governorate } & Area & \multicolumn{3}{l}{ Number of trees } \\
\cline { 2 - 5 } & $($ ha) & $\%$ & Trees & 49 \\
\hline Kebili & 15,450 & 43 & $2,190,072$ & 35 \\
Tozeur & 8,000 & 22 & $1,575,130$ & 11 \\
Gabes & 7,000 & 19 & 510,000 & 4 \\
Gafsa & 4,500 & 13 & 188,723 & 0.8 \\
Medenine & 750 & 2 & 40,000 & 1.5 \\
Tataouine & 300 & 1 & 7,000 & 100 \\
Total & 36,000 & 100 & $4,510,925$ & \\
\hline
\end{tabular}

Table 2 Studied cultivars in Tunisian costal oases.

\begin{tabular}{lll}
\hline Cultivar & Color of "Blah" stage & Stage of consumption \\
\hline Ammari (AM) & Yellow & Rtob \\
Bouhattam (BO) & Yellow & Blah \\
Eguiwa (EG) & Yellow & Tamr \\
Feliane (FE) & Yellow & Tamr \\
Ftimi (FT) & Yellow red & Tamr \\
Garn Ghazel (GG) & Yellow dark & Tamr \\
Halwai Abiadh (HA) & Yellow & Rtob, Tamr \\
Kenta (KE) & Yellow & Tamr \\
Korkobbi (KO) & Yellow & Blah, Rtob \\
Ksebba (KS) & Yellow & Tamr \\
Lemsi (LE) & Yellow-red & Blah \\
Mattata (MA) & Green-yellow & Blah \\
Mermella (ME) & Yellow & Tamr \\
Rochdi (RO) & Yellow & Blah \\
Smiti (SM) & Yellow & Tamr \\
\hline
\end{tabular}




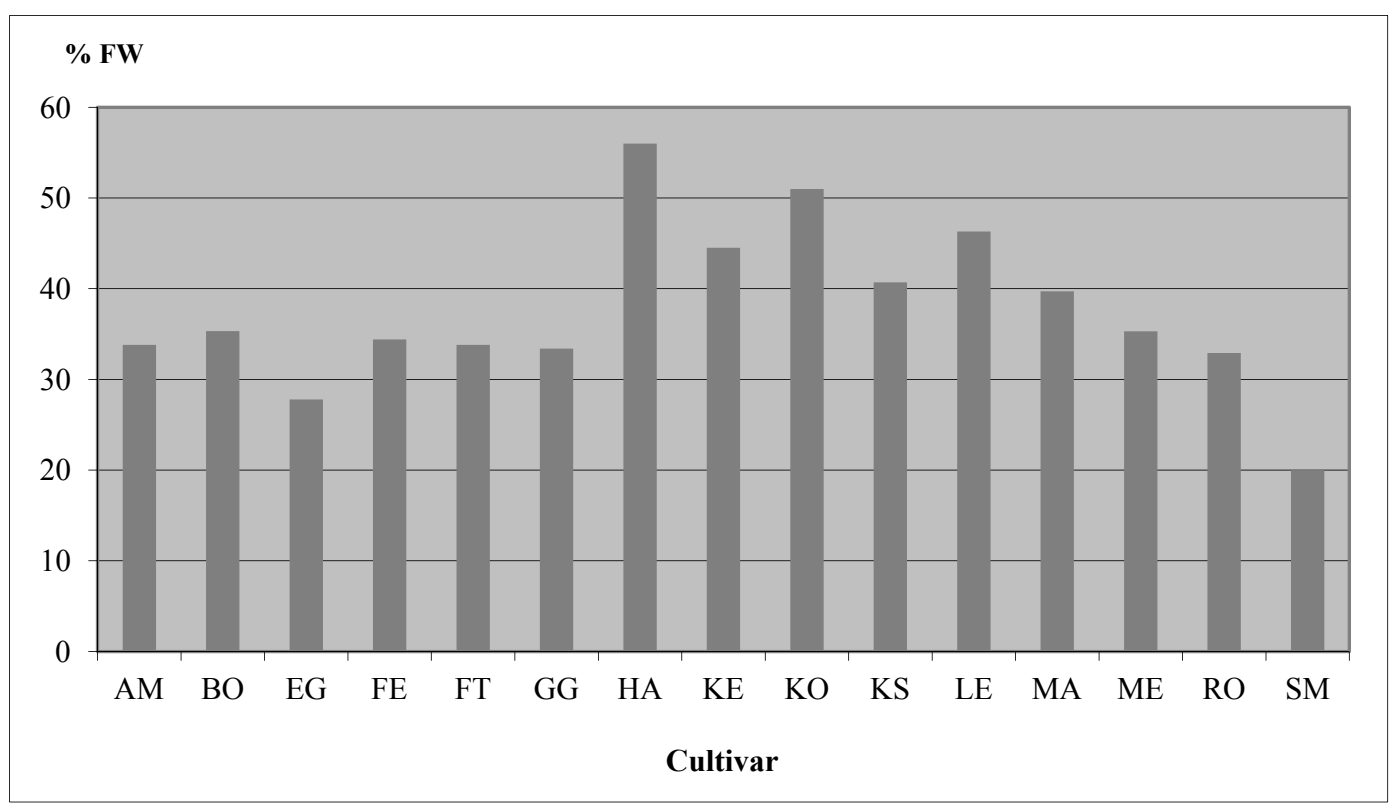

Fig. 1 Water content (moisture) in fresh flesh of dates of different coastal cultivars (\% MF).

Table 3 Analysis of variance of the moisture of coastal date cultivars of Tunisian coastal oases.

\begin{tabular}{ll}
\hline Cultivar & Groups $(1)$ \\
\hline HA & $56.000 \mathrm{a}$ \\
KO & $51.000 \mathrm{ab}$ \\
LE & $46.500 \mathrm{bc}$ \\
KE & $44.500 \mathrm{bc}$ \\
KS & $41.000 \mathrm{bcd}$ \\
MA & $40.000 \mathrm{bcd}$ \\
ME & $35.500 \mathrm{~cd}$ \\
BO & $35.500 \mathrm{~cd}$ \\
FE & $34.500 \mathrm{~cd}$ \\
AM & $34.000 \mathrm{~cd}$ \\
FT & $33.500 \mathrm{~cd}$ \\
GG & $33.000 \mathrm{~cd}$ \\
RO & $33.000 \mathrm{~cd}$ \\
EG & $27.950 \mathrm{~d}$ \\
SM & $20.000 \mathrm{e}$ \\
\hline$P=0.001$
\end{tabular}

$P=0.0001$.

\subsection{Sugar Content}

Sugar composition of date cultivars on coastal oasis (Fig. 2) shows values ranging from $25 \%$ to $66 \%$ of fresh flesh by each cultivar. Statistical analysis by ANOVA (Table 4) showed significant difference between cultivars in their content of reducing sugars, sucrose and total sugars. Dates of coastal cultivars, except "Garn Ghazel" have proved to be rather rich compared to "Deglet Nour" sugars. The rate of sugars in the "Deglet Nour" dates is $81 \%$ of the pulp weight $[2,3,13-15]$. Relating to the nature of the sugars in the dates, sugars of most cultivars are glucose and fructose, excepting "Garn Ghazel" for which the rate of sucrose is $30 \%$ of the total date sugars.

\subsection{Acidity of Dates}

The degree of acidity in dates (Fig. 3) varies from 4.9 to 6.2. Statistical analysis (Table 5) showed no significant difference between cultivars in acidity of 


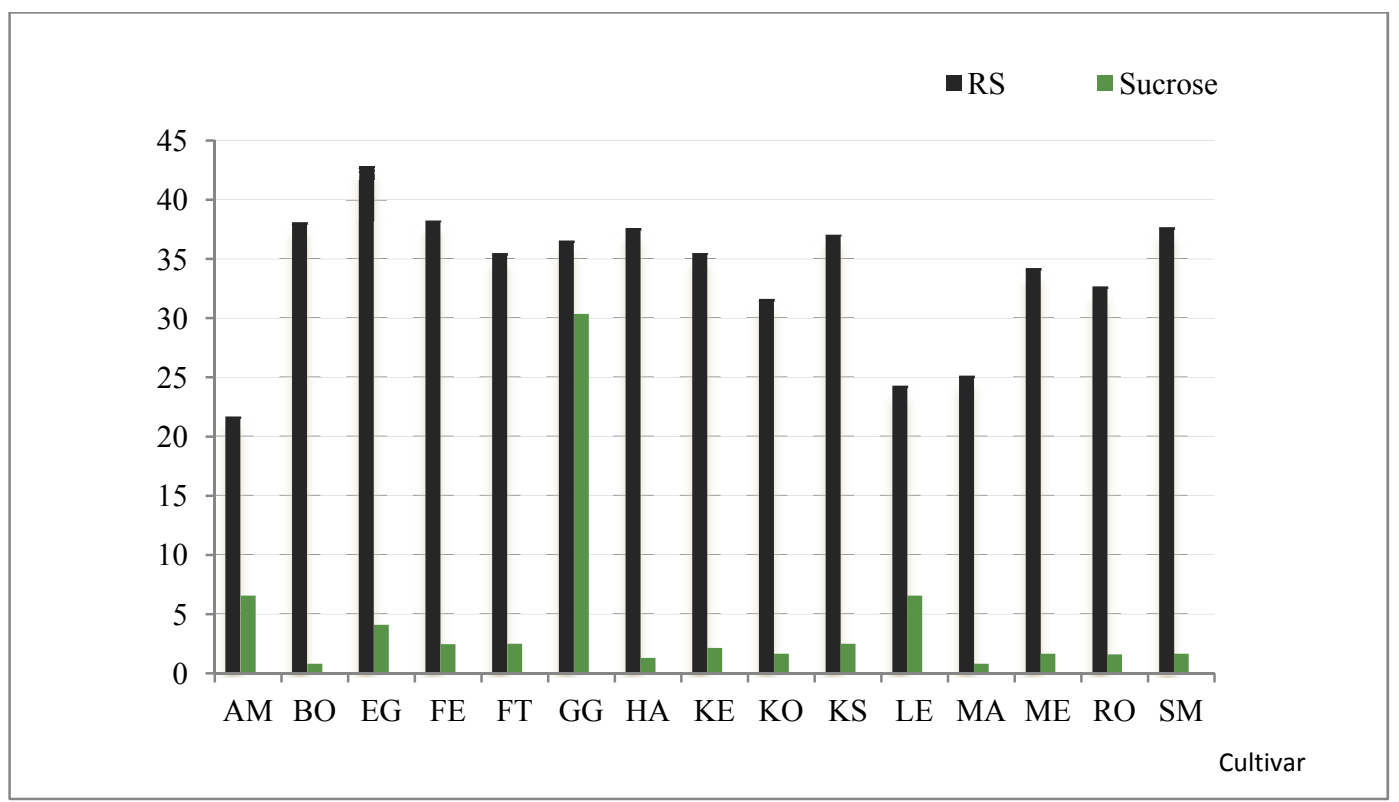

Fig. 2 Composition of reducing sugars (RS) and sucrose (S) in fruits of coastal date cultivars (\% FM).

Table 4 Anova composition of coastal dates cultivars of sucrose, reducing and total sugars.

\begin{tabular}{|c|c|c|c|c|c|}
\hline \multicolumn{2}{|c|}{ Sucrose } & \multicolumn{2}{|c|}{ Reducing sugars } & \multicolumn{2}{|c|}{ Total sugars } \\
\hline Cultivar & Groups & Cultivar & Groups & Cultivar & Groups \\
\hline GG & $30.358 \mathrm{a}$ & EG & $47.445 a$ & GG & $66.858 \mathrm{a}$ \\
\hline $\mathrm{AM}$ & $6.564 b$ & FE & $38.250 \mathrm{ab}$ & EG & $51.547 \mathrm{~b}$ \\
\hline LE & $6.564 b$ & $\mathrm{BO}$ & $38.080 \mathrm{ab}$ & FE & $40.712 b c$ \\
\hline EG & $4.103 \mathrm{c}$ & SM & $37.650 \mathrm{ab}$ & SM & $39.290 b c$ \\
\hline KS & $2.500 \mathrm{~cd}$ & HA & $37.555 \mathrm{ab}$ & KS & $39.040 \mathrm{bc}$ \\
\hline FT & $2.500 \mathrm{~cd}$ & KS & $36.540 \mathrm{ab}$ & $\mathrm{BO}$ & $38.880 \mathrm{bc}$ \\
\hline $\mathrm{FE}$ & $2.462 \mathrm{~cd}$ & GG & $36.500 \mathrm{ab}$ & HA & $38.855 b c$ \\
\hline $\mathrm{KE}$ & $2.133 \mathrm{~cd}$ & $\mathrm{KE}$ & $35.490 \mathrm{ab}$ & FT & $37.975 \mathrm{c}$ \\
\hline $\mathrm{KO}$ & $1.641 \mathrm{~cd}$ & $\mathrm{FT}$ & $35.475 \mathrm{ab}$ & $\mathrm{KE}$ & $37.623 \mathrm{c}$ \\
\hline $\mathrm{ME}$ & $1.641 \mathrm{~cd}$ & $\mathrm{ME}$ & $34.190 \mathrm{ab}$ & ME & $35.831 \mathrm{c}$ \\
\hline SM & $1.640 \mathrm{~cd}$ & RO & $32.640 \mathrm{ab}$ & RO & $34.240 \mathrm{c}$ \\
\hline RO & $1.600 \mathrm{~cd}$ & $\mathrm{KO}$ & $31.595 \mathrm{ab}$ & $\mathrm{KO}$ & $33.236 \mathrm{c}$ \\
\hline HA & $1.300 \mathrm{~cd}$ & MA & $25.105 b$ & LE & $30.814 c$ \\
\hline MA & $0.800 \mathrm{~d}$ & LE & $24.250 \mathrm{~b}$ & $\mathrm{AM}$ & $28.204 c$ \\
\hline $\mathrm{BO}$ & $0.800 \mathrm{~d}$ & $\mathrm{AM}$ & $21.640 \mathrm{~b}$ & MA & $25.905 \mathrm{c}$ \\
\hline
\end{tabular}

P sucrose $=0.0029$

P reducing sugars $=0.0001$.

$\mathrm{P}$ total sugars $=0.0001$.

dates. The degree of acidity is considered as the criteria of quality [13]. Dates with a low level of acidity are considered of a poor quality. According to many authors $[5,6,13] \mathrm{pH}$ of dates is generally sited between from 4.5 to 7 . Equally it was found that the
$\mathrm{pH}$ of the "Barhi" of Iraqi origin cultivar is 7.2 [13]. On the other hand, the $\mathrm{pH}$ was 4 in the "BesserHelou" cultivar cultivated in the region of Jerid in Tunisia [6]. The $\mathrm{pH}$ of among 91 eastern Algerian cultivars was 1.8 for $8[16]$. 


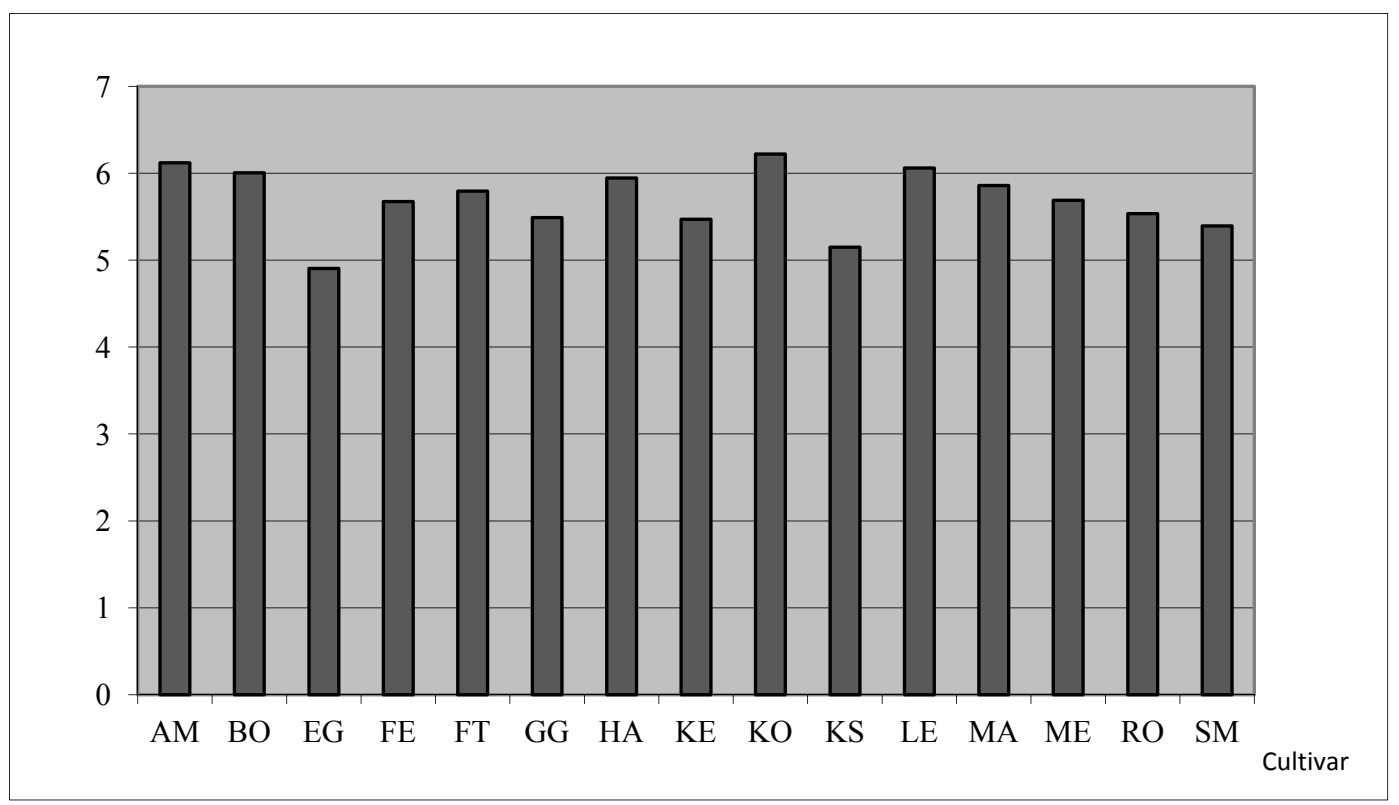

Fig. 3 Date acidity in fruits of coastal date palm cultivars.

Table 5 Analysis of variance of the acidity of the dates of different cultivars of Tunisian coastal oases.

\begin{tabular}{ll}
\hline Cultivar & Groups \\
\hline KO & $6.220 \mathrm{a}$ \\
AM & $6.120 \mathrm{a}$ \\
LE & $6.060 \mathrm{a}$ \\
BO & $6.005 \mathrm{a}$ \\
HA & $5.900 \mathrm{a}$ \\
MA & $5.860 \mathrm{a}$ \\
FT & $5.795 \mathrm{a}$ \\
ME & $5.690 \mathrm{a}$ \\
FE & $5.675 \mathrm{a}$ \\
RO & $5.535 \mathrm{a}$ \\
GG & $5.490 \mathrm{a}$ \\
KE & $5.470 \mathrm{a}$ \\
SM & $5.395 \mathrm{a}$ \\
KS & $5.150 \mathrm{a}$ \\
EG & $4.905 \mathrm{a}$ \\
\hline
\end{tabular}

$\mathrm{P}=0.8381$.

\subsection{Total Nitrogen}

The results of coastal date's cultivars (Fig. 4) show rates of Total Nitrogen in date varying from 1 for "Rochdi" to 4\% in "Kenta" and "Mattata". Other cultivars are about $2 \%$ to $3 \%$. Statistic analysis (Table 6) showed significant difference in the level of $1 \%$ between cultivars. Total nitrogenous matter is the total of proteins, amino acids and other nitrogen compounds in dates [17]. It was indicate a rate of $0.98 \%$ fresh weight of the date pulp of Moroccan cultivars [5]. A rate of $1.43 \%$ of the weight of the Algerian cultivar "Degla" pulp was reported [5]. Many other studies were interested in the rate of proteins in dates as in 12 Sudanese cultivars $2.06 \%$ to $4.06 \%$ of dry fruit weight [15] and $1.5 \%$ to $2 \%$ of the dry weight in the Moroccan cultivars [17]. The rate was higher in 6 cultivars cultivated in the United Arab Emirates than those in Kuwait from $1.7 \%$ to $5.8 \%$ of weight of dry matter [14]. 


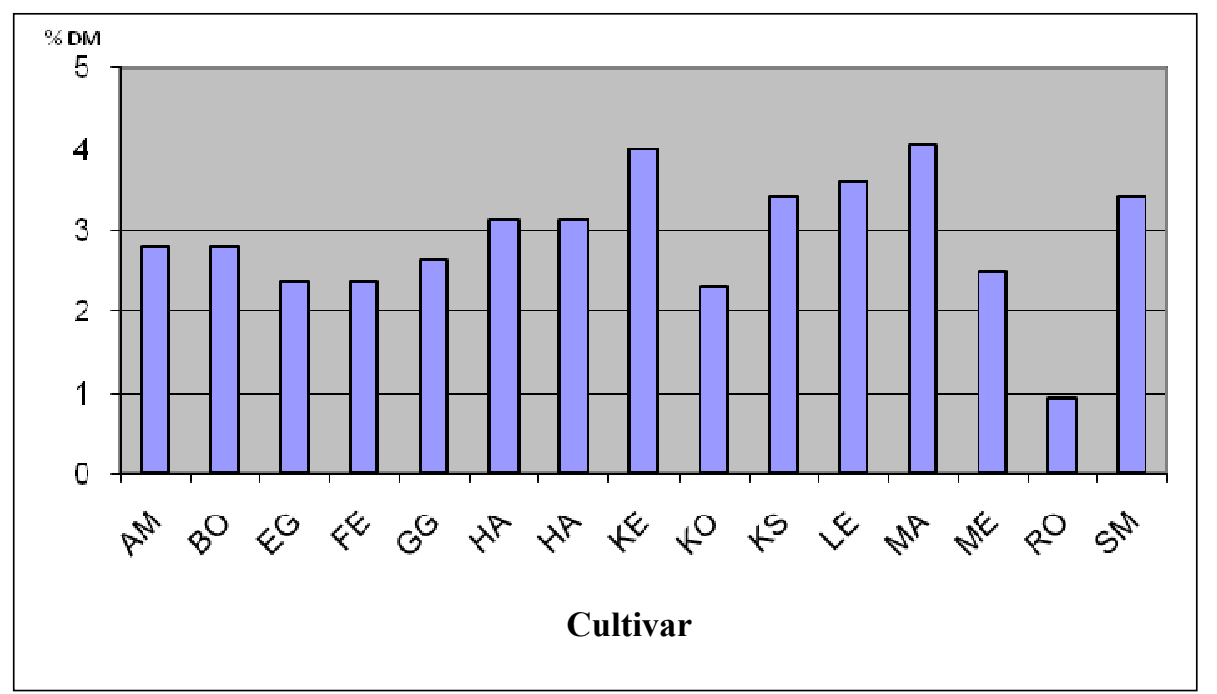

Fig. 4 Total Nitrogen dates palm cultivars in coastal oases in dry matter (\% DM).

Table 6 Analysis of variance of Total Nitrogen on the dates of different cultivars of Tunisian coastal oases.

\begin{tabular}{ll}
\hline Cultivars & Groups \\
\hline MA & $4.060 \mathrm{a}$ \\
KE & $4.000 \mathrm{a}$ \\
LE & $3.600 \mathrm{ab}$ \\
SM & $3.430 \mathrm{ab}$ \\
KS & $3.430 \mathrm{ab}$ \\
HA & $3.130 \mathrm{ab}$ \\
GG & $3.120 \mathrm{ab}$ \\
AM & $2.810 \mathrm{ab}$ \\
BO & $2.800 \mathrm{ab}$ \\
FT & $2.620 \mathrm{~b}$ \\
ME & $2.500 \mathrm{~b}$ \\
FE & $2.370 \mathrm{~b}$ \\
EG & $2.370 \mathrm{~b}$ \\
KO & $2.310 \mathrm{~b}$ \\
RO & $0.930 \mathrm{c}$ \\
\hline
\end{tabular}

$\mathrm{P}=0.0001$.

\subsection{Minerals}

The mineral composition of coastal cultivars (Table 7) shows that sodium rate varies from $0.01 \%$ of the DM (dry matter) of "Ammari" cultivar up to $0.1 \%$. The highest $\mathrm{P}$ in dates levels are $0.85-0.87 \%$ for "Smiti" and "Halwai Abiadh" cultivars. The minimum rate is found in "Kenta" $(0.20 \%)$. "Ksebba" is the richest cultivar in $\mathrm{Na}$. "Ammari" and "Smiti", follow with a rate of $0.97 \%$. As far as $\mathrm{Ca}$ is concerned, the maximum rate is $0.7 \%$ for the "Rochdi" cultivar. Cultivars which contain the least $\mathrm{Ca}$ are "Korkobbi",
"Ftimi", "Garn Ghazel", "Ksebba" (0.07\% to $0.08 \%)$. Statistic analysis showed no significant difference between cultivars. It was reportedthat Algerian dates composition rates of $0.08 \%$ of the fresh weight of $\mathrm{Ca}$ and $0.02 \%$ of $\mathrm{P}$ [5]. The mineral composition of "DegletNour" dry flesh dates showed $0.34 \%$ of $\mathrm{K}$, $0.10 \%$ of $\mathrm{P}, 0.03 \%$ of $\mathrm{Ca}$ and $0.09 \%$ of $\mathrm{Na}$ [13]. In 49 Saudi date palm cultivars [8] and in 4 Iraqi cultivars [18] K went beyond all other minerals. It was also proved the high content of $\mathrm{K}$ in the dates of 21 Tunisian cultivars from JeridSaharan oases [6]. 
Table 7 Mineral composition of coastal dates (\% DM).

\begin{tabular}{lllll}
\hline Cultivar & $\mathrm{P}$ & $\mathrm{K}$ & $\mathrm{Na}$ & $\mathrm{Ca}$ \\
\hline AM & 0.77 & 0.97 & 0.01 & 0.20 \\
BO & 0.30 & 0.53 & 0.06 & 0.22 \\
EG & 0.60 & 0.85 & 0.02 & 0.20 \\
FE & 0.75 & 0.75 & 0.05 & 0.20 \\
FT & 0.75 & 0.05 & 0.07 \\
GG & 0.50 & 0.67 & 0.07 & 0.07 \\
HA & 0.50 & 0.80 & 0.02 & 0.10 \\
KE & 0.85 & 0.35 & 0.09 & 0.25 \\
KO & 0.20 & 0.60 & 0.03 & 0.08 \\
KS & 0.70 & 1.30 & 0.05 & 0.07 \\
LE & 0.65 & 0.70 & 0.08 & 0.20 \\
MA & 0.30 & 0.75 & 0.02 & 0.20 \\
ME & 0.72 & 0.75 & 0.10 & 0.52 \\
RO & 0.40 & 0.85 & 0.05 & 0.70 \\
SM & 0.65 & 0.97 & 0.02 & 0.35 \\
\hline
\end{tabular}

\section{Conclusions}

The coastal oases are close to the fifth area of the total Tunisian oases and have, for a long time, preserved a rich and varied date palm cultivar biodiversity. Coastal dates are distinguished by their consistency as soft dates. The chemical composition shows that the coastal cultivars are rich of reducing sugars and poor in sucrose. This richness classifies the coastal date as dietary important aliment. Their $\mathrm{pH}$ is relatively high, which is appreciate and considered as criteria of quality. The mineral composition shows that the dates are rich on $\mathrm{P}$ and $\mathrm{K}$, what qualify that the dates are good aliment.

\section{References}

[1] GID (Groupement Inter-professionaldes Dattes), Tunisie, 2004. Annual report (in Arabic).

[2] Kassah, A. 1996. "The Date Palm Tunisian Sector."Tunisian Review of Geography18:201-35 (in French).

[3] Munier, P. 1973. The Date Palm Palm Tree. Paris: Maisonneuve \& Larose (in French).

[4] NF V 76-106 (Certified French Standard), 1980. Determination of sucrose, D-fructose and D-glucose in juice of fruits and vegetables by enzymatic method.

[5] Patron, A., Patron, S., and Swinsow, H. 1954. "The Chemical Composition of the Moroccan Dates Considered from the Perspective of Their Food Value." Fruits 9 (10): 443-9.
[6] Reynes, M., Bouabidi, H., Piombo, G., and Risterucci, A. M. 1994. "Characterization of Main Date Palm Cultivars Grown in the Region of Djerid-Tunisia." Fruit. 49 (4): 289-98 (in French).

[7] Rhouma, A. 1994. The Date Palm Comes to Tunisia Palm. Genetic heritage. Arabesques. Editions and creations. Tunis. Tunisia (in French).

[8] Sawaya, W. N., Miski, A. M., Khalil, J., Khatchadourian, H. A., and Mashadi, A. S. 1983. "Physical and Chemical Characterization of the Major Date Cultivars Grown in Saudi Arabia 1-Morphological Measurements, Proximate and Mineral Analysis." Date Palm J. 2 (1): 1-25.

[9] Ben Salah, M. 1992. First directory of date palm in Tunisian coastal oases: Proceedings of the International Meeting: Oases in Tunisia, World Heritage: UNESCO, ALECSO Chenini club. Tunisian Federation of UNESCO, ALECSO clubs. Chenini- Gabès, December 27-30, 1992. (in French).

[10] Ben Salah, M., and Hellali, H. 2006. "Phenopomological Description of 15 Date Palm (Phoenix dactylifera L.) Tunisian Cultivars."Plant Genetic Resources Newsletter IPGRI-FAO. 148: 10-8.

[11] Bouabidi, H., Reynes, M., and Rouissi, M. B. 1996. "Criteria for Characterization of the Fruits of Some Date Palm Cultivars (Phoenix dactylifera L.) of the Tunisian South Oases." Ann. Ins. Nat. Agr. Tunisia. 69: 73-87 (in French).

[12] Harrak, H., Hamouda, A., Boujnah, M., and Gaboune, F. 2005. "Levels of Sugar and Nutritional Main Cultivars of Moroccan Dates and Technological Qualities.” Presented at the International Symposium on Sustainable Development Oases Systems, Erfoud, Morocco (in French). 
[13] El Bekr, A. 1972. "The Date Palm: Review of Its Past, Present Status and the Recent Advances in Its Culture Industry and Trade." Imp. El Ani. Bagdad. Irak p. 1050 (in Arabic).

[14] El Houti, S., Jiwan-Sidhu, S., and Qabazard, H. 1995. "Studies on the Physico-Chemical Characteristics of Dates of Five UAE Date Palm Cultivars at Different Stages of Maturity."Arab Gulf J. Scient. Res. 13: 553-69.

[15] Khalifa, T. A., and SidAhmed, O. A. 1986. "Physico-Chemical Evaluation of Fruits of Some Sudanese Date Cultivars." Trop. Agric. (Trinidad) 56 (2): $117-20$.
[16] Belguedj, M. 2002. "Genetic Resources of the Date Palm, Characteristics of Cultivars Groves of the Algerian South-East." Algerian National Institute of Agronomic Research. Algeria. (in French).

[17] Vandercook, C. E., Hasegawa, S., and Mayer, V. P. 1979. "Quality and Nutritive Value of Dates as Influenced by Their Chemical Composition." Date Growers' Inst. Rep. 54: 3 .

[18] Yousif, K. A., Benjamin, N. D., Kado, A., Shefa, M. A., and Saad, M. A. 1982. "Chemical Composition of Four Iraqi Date Palm Cultivars." Date Palm J. 1 (2): 285-94. 